\title{
Pelatihan Pembuatan Alat Peraga Ilmu Pengetahuan Bumi Antariksa bagi Kelompok Guru SMP dan SMA Lab. Undiksha Singaraja
}

\section{Ni Made Pujani*}

1Jurusan Pendidikan IPA FMIPA Undiksha

A R T I C L E I N F O

Article history:

Received 16

Oktober 2017

Received in revised

form

6 November 2017

Accepted 12 januari

2018

Available online 20

Februari 2018

Kata Kunci:
alat peraga, Ilmu
Pengetahuan Bumi
Antariksa, inkuiri
Keywords:
Teaching aid,
Geography and
Outer Space, Inquiry

Kata Kunci:

alat peraga, IImu

Pengetahuan Bumi

Keywords:

Geography and

Outer Space, Inquiry

\begin{abstract}
A B S T R A K
Kegiatan pengabdian Ipteks bagi Masyarakat (IbM) ini dilakukan bagi guru-guru pengajar IImu Pengetahuan Bumi dan Antariksa (IPBA) di SMP dan SMA Lab Undiksha Singaraja. Kegiatan dilakukan dalam bentuk pelatihan dan pendampingan pembuatan alat peraga IPBA, pelatihan dan pendampingan penyusunan perangkat pembelajaran menggunakan pendekatan inkuiri, dan pendampingan implementasi pembelajaran IPBA menggunakan alat yang diproduksi. Kegiatan ini bertujuan untuk meningkatkan pengetahuan dan keterampilan praktikum bagi kelompok guru pengajar IPBA di SMP dan SMA Lab. Undiksha Singaraja guna menanggulangi kendala pembelajaran IPBA. Pelaksanaan inti kegiatan dalam bentuk in service dan on service mulai tanggal 16 Juni 2017 - 30 Oktober 2017. Evaluasi kegiatan dilakukan terhadap proses dan output kegiatan. Hasil evaluasi menunjukkan bahwa kegiatan IbM bagi guru pengajar IPBA di SMP dan SMA Lab. Undiksha berlangsung dengan baik sesuai yang direncanakan. Guruguru dari sekolah mitra antusias dan terlibat dengan aktif dalam mengikuti kegiatan. Hampir semua guru mitra sudah mampu meningkatkan keterampilannya dalam mengembangkan perangkat pembelajaran IPBA menggunakan pendekatan inkuiri, sudah mampu membuat alat peraga sesuai LKS yang dikembangkan, serta mampu mengimplementasikan perangkat dan alat peraga yang diproduksi dalam pembelajaran di kelas
\end{abstract}

\begin{abstract}
A B S T R A C T
This service on Science and Technology for Community (IbM) was done for the teachers who teach Geography and Outer Space (IPBA) at SMP and SMA Lab Undiksha Singaraja. The activity was done in the form of training and tutoring in making teaching aids for IPBA, the training and tuturing in materials development used inquiry approach, and the tutoring was implemented in IPBA teaching using materials that had been developed. This activity was aimed at improving knowledge and skill in practicum for the group of teachers of IPBA at SMP and SMA Lab. Undiksha Singaraja to solve the constraints in the teaching of IPBA. The core implementation in the form of in service and on service was started on $16^{\text {th }}$ June, 2017 until $30^{\text {th }}$ October, 2017. The evaluation of the activity jwas done to the process and the output of the activity. The results of the evaluation showed that the IbM activity for the teachers of IPBA at SMP and SMA Lab. Undiksha ran well according to the plan. The teachers at the partner school were enthusiastic and engaged in the activity. Almost all of them were able to improve their skill in developing teaching materials for IPBA using inquiry approach,
\end{abstract}

\footnotetext{
* Corresponding author.

E-mail addresses: made.pujani@ undiksha.ac.id (Ni Made Pujiani),
} 
they could make teaching aids according to Student's Worksheets developed, and were able to implement the materials and teaching aids produced in teaching in the classroom.

Copyright (C) Universitas Pendidikan Ganesha. All rights reserved.

\section{Pendahuluan}

Hasil analisis situasi menunjukkan bahwa guru-guru pengajar IPBA di SMP dan SMA Laboratorium Undiksha Singaraja, masih mengalami permasalahan dalam mengelola pembelajaran dengan kegiatan praktikum dan pendekatan inkuiri. Salah satu faktor penyebabnya adalah minimnya sarana-prasarana penunjang seperti alat dan bahan laboratorium. Keberadaan laboratorium merupakan aspek yang penting dalam pembelajaran IPBA. Hal tersebut diungkapkan oleh kepala sekolah SMP dan SMA Lab. Undiksha saat berdiskusi dengan tim P2M pada kegiatan observasi.

Dari hasil wawancara dengan kepala sekolah dan hasil observasi di SMP dan SMA Lab. Undiksha diperoleh informasi bahwa pembelajaran IPBA masih cenderung menggunakan metode informasi dan diskusi. Guru-guru pengajar IPBA masih mengalami kesulitan dalam menerapkan pendektaan ilmiah dalam pembelajaran inovatif sesuai dengan hakikat sains (NRC, 2002), yang memberikan penekanan pada proses sekaligus produk sains.

SMP Lab. Undiksha dibangun di atas tanah seluas : $(700 \times 320) \mathrm{m} 2$. Terdapat Lab IPA, Lab Komputer, dan Perpustakaan dengan jumlah ruang kelas = 18 (Profil SMP Lab. Undiksha, 2017). Jumlah maupun luas bangunan, baik ruangan kelas, perpustakaan, maupun laboratorium yang dimiliki cukup memadai. Ruang laboratorium IPA terdiri atas ruang praktikum, ruang persiapan, dan ruang alat dan bahan. Ruang alat/bahan berisi 2 buah rak/almari. Walaupun ruang laboratoriumnya sudah cukup memadai, namun jumlah alat/bahan praktikum IPBA yang dimiliki masih sangat terbatas.

SMA Lab. Undiksha lokasinya menjadi satu dengan SMP Lab. Undiksha karena berada dibawah yayasan yang sama. Pola bangunan SMA Lab. dan ukuran kelas di SMA sama dengan di SMP Lab. UNDIKSHA. Jumlah kelas ada 18 ruang kelas, sebuah perpustakaan, sebuah ruang laboratorium IPA, Lab. Bahasa, Lab. Komputer dan perpustakaan. Ruang laboratorium Fisika ukurannya sama seperti di Lab. IPA di SMP. Ruang lab, dibagi menjadi ruang praktikum, ruang alat/bahan, dan ruang persiapan. Pada ruang alat/bahan terdapat rak alat tempat penyimpanan alat/bahan praktikum (Profil SMA Lab. Undiksha, 2017). Ruangan untuk persiapan kurang menunjukkan fungsinya, malahan menjadi tempat meletakkan kertas-kertas karena ukurannya sempit. Keberadaan alat dan bahan praktikum di laboratorium Fisika SMA Lab. Undiskha masih terbatas dan kurang ditata dengan baik. Sementara sejumlah alat yang dimiliki spesifikasinya kadang tidak sesuai dengan kebutuhan. Pengadaan alat dan bahan kurang menjadi prioritas sekolah karena keterbatasan dana pengadaan.

Hal serupa juga diungkapkan oleh guru pengajar IPBA di SMP dan SMA Lab. Undiksha yang menyatakan pembelajaran menggunakan pendekatan inkuiri sangat jarang dilakukan disebabkan oleh keterbatasan sarana praktikum, dan tidak adanya laboratorium. Bagi guru, praktikum dirasa menyita waktu dan tenaga yang sangat besar sehingga enggan dilakukan. Walaupun persediaan alat dan bahan praktikum sangat terbatas, guru pengajar IPBA telah mencoba memanfaatkan bahan-bahan yang ada di lingkungan sekitar. Namum karena alasan keterbatasan pengetahuan dan waktu, kiat-kiat kreatif yang dapat dilakukan oleh guru masih sangat terbatas, bahkan hampir belum pernah membuat alat peraga untuk praktikum IPBA. Guru menyatakan enggan berinovasi, karena alasan belum mampu untuk melakukan itu. Penyiapan praktikum justru dirasa sebagai beban tambahan, bukan sebagai sesuatu yang dapat membantu proses pembelajaran. Hal ini menunjukkan bahwa pembelajaran dengan pendekatan inkuiri belum dipahami dengan baik.

Hasil wawancara lebih lanjut dengan guru pengajar IPBA dikedua sekolah menemukan bahwa para guru juga mengalami kesulitan dalam mengimplementasikan pembelajaran terkait materi IPBA. Hal ini karena latar belakang pendidikan guru bukan IPBA, sesungguhnya adalah pendidikan biologi atau pendidikan fisika atau pendidikan kimia, sehingga ketika masuk ke materi IPBA aspek keilmuannya ada di luar bidang yang dikuasai. Akibatnya guru bersangkutan mengalami kendala. Hal tersebut sangat berpotensi menjadi sumber miskonsepsi.

Berdasarkan hasil observasi di SMP dan SMA Lab. Udiksha diketahui keberadaan laboratorium IPA dan Fisika masih kurang tertata. Alat-alat yang ada tidak tertangani dengan baik dan tidak dapat difungsikan secara optimal. Disamping karena sudah rusak, spesifikasi dan komponen-komponen alat yang ada tidak sesuai dengan rancangan alat praktikum pada petunjuk praktikum pegangan guru. Hal ini 
menunjukkan bahwa pengelolaan, pemanfaatan dan pemberdayaan laboratorium IPA dan Fisika di sekolah tersebut belum berlangsung dengan baik.

Kurangnya dukungan sarana untuk mengimplementasikan pembelajaran inovatif sesuai dengan hakekat sains merupakan penyebab utama yang disampaikan guru mitra terhadap masih rendahnya atmosfir belajar dan hasil belajar IPBA siswa. Pembelajaran menggunakan pendekatan inkuiri yang menekankan proses dan produk sulit dilakukan tanpa dukungan dari ketersediaan alat, bahan praktikum, dan bahan ajar yang lain. Pembelajaran IPBA menjadi sulit dilakukan melalui kerja ilmiah di laboratorium.

Permasalahan yang dikemukakan di atas sampai sekarang belum memperoleh solusi yang tepat. Selain aspek sarana dan prasarana, guru-guru mitra menyadari bahwa mereka belum memiliki keterampilan yang memadai dalam mengelola pembelajaran menggunakan pendekatan ilmiah (scientific appoach) dalam IPBA. Guru kurang memperoleh inservice tentang pembelajaran IPBA menggunakan metode eksperimen dan demonstrasi (Pujani dan Rapi, 2012, 2013). Guru belum biasa memanfaatkan lingkungan sebagai laboratorium dalam memfasilitasi kegiatan inkuiri siswa dibidang IPBA. Beberapa permasalahan yang dihadapi guru dalam mengelola kegiatan inkuiri dan discovery, seperti: (1) pemilihan fenomena atau kasus kontekstual yang relevan dengan konsep dan prinsip yang ditekankan dalam pembelajaran; (2) mengarahkan pengamatan siswa dalam praktikum. Guru yang kreatif yang memiliki keterampilan mengelola kegiatan inkuiri discovery sebenarnya potensial dalam mengembangkan alternatif pembelajaran menggunakan pendekatan ilmiah dengan memanfaatkan alat/bahan yang ada di lingungan kita.

Guru mitra mengungkapkan bahwa mereka dari dulu sangat ingin memiliki keterampilan mengelola pembelajaran IPBA dengan praktikum. Mereka ingin memiliki kemampuan dalam membuat media berupa alat peraga praktikum IPBA sederhana yang mudah diterapkan. Mereka juga mengemukakan bahwa pembekalan/pemantapan materi IPBA masih sangat dibutuhkan, karena keahlian guru masih banyak yang mish match. Guru-guru sangat berharap melalui kegiatan pengabdian masyarakat (IbM) ini keinginan mereka akan dapat diwujudkan.

Bertolak dari fenomena yang diuraikan di atas maka untuk mewujudkan peran strategis laboratorium dalam pembelajaran IPBA, maka upaya untuk meningkatkan kompetensi pengelolaan laboratorium dan pengembangan alat peraga praktikum IPBA di SMP dan SMA Lab UNDIKSHA, serta pengembangan perangkat pembelajaran IPBA sangat diperlukan. Oleh karena itu perlu dilakukan IbM bagi guru-guru pengajar IPBA yaitu guru-guru IPA, IPS SMP dan guru-guru Fisika, Geografi SMA di sekolah mitra (SMP dan SMA Lab. Undiksha) agar guru-guru di sekolah mitra memiliki keterampilan dalam pengelolaan laboratorium sebagai penunjang pembelajaran IPBA, merancang alat peraga praktikum pembelajaran IPBA, serta merancang pembelajaran menggunakan pendekatan inkuiri dan discovery berbantuan alat peraga IPBA. Bekal keterampilan serta produk yang dihasilkan guru diharapkan dapat digunakan dan disempurnakan secara berkelanjutan sehingga sekolah mitra ini bisa lebih mandiri dan menjadi inisiator pengembang pembelajaran IPBA.

Adapun tujuan program IbM ini adalah (1) untuk meningkatkan keterampilan membuat alat peraga praktikum IPBA dari bahan yang ada di lingkungan sekitar sebagai penunjang pembelajaran IPBA menggunakan pendekatan inkuiri, (2) meningkatkan penguasaan guru dalam menyusun perangkat dan materi IPBA bagi guru-guru IPA/IPS di SMP dan guru Fisika/Geografi di SMA, dan (3) meningkatkan kemampuan guru-guru dalam menerapkan pembelajaran IPBA menggunakan inkuiri.

\section{Metode}

Metode yang diterapkan dalam pengabdian ini adalah aplikasi teknologi pembelajaran, dengan mengungkap permasalahan yang muncul dikalangan para guru, kemudian dilakukan diskusi pengusul bersama mitra untuk merumuskan akar masalah dan prioritas masalah yang disepakati, serta menentukan solusi yang tepat. Secara garis besar langkah-langkah pelaksanaan seperti pada Tabel 1 berikut.

Tabel 1 Keterkaitan antara Masalah Mitra dengan Solusi Pemecahan

\begin{tabular}{|c|c|c|}
\hline $\begin{array}{c}\text { Dua Permasalahan Pokok } \\
\text { yang Dipecahkan }\end{array}$ & Akar Permasalahan & $\begin{array}{c}\text { Pendekatan Pemecahan } \\
\text { Masalah (Solusi) }\end{array}$ \\
\hline $\begin{array}{lr}\text { 1. Kuantitas dan } & \text { efektivitas } \\
\text { alat dan } & \text { bahan } \\
\text { laboratorium } & \text { sebagai } \\
\text { media } & \text { penunjang } \\
\text { pembelajaran/praktikum }\end{array}$ & $\begin{array}{l}\text { 1. Guru-guru pengajar IPBA kurang } \\
\text { terampil dalam membuat alat } \\
\text { peraga praktikum IPBA dengan } \\
\text { bahan yang ada di lingkungan } \\
\text { yang lebih praktis dan efektif }\end{array}$ & $\begin{array}{l}\text { 1. Memberikan pelatihan dan } \\
\text { pendampingan merancang } \\
\text { dan membuat alat peraga } \\
\text { praktikum IPBA. } \\
\text { 2. Melatih kreativitas dan }\end{array}$ \\
\hline
\end{tabular}




\begin{tabular}{|c|c|c|}
\hline $\begin{array}{l}\text { IPBA menggunakan } \\
\text { pendekatan inkuiri belum } \\
\text { memadai }\end{array}$ & $\begin{array}{l}\text { sebagai pendukung pembelajaran } \\
\text { menggunakan pendekatan inkuiri. } \\
\text { 2. Rendahnya kreativitas dan } \\
\text { kemampuan berinovasi dalam } \\
\text { memanfatkan lingkungan sebagai } \\
\text { sumber bahan praktikum dalam } \\
\text { pembelajaran IPBA. }\end{array}$ & $\begin{array}{l}\text { kemampuan inovatif dalam } \\
\text { merancang model-model } \\
\text { praktikum dari alat dan bahan } \\
\text { yang ada di lingkungan sekitar }\end{array}$ \\
\hline $\begin{array}{lr}\text { 2. Guru pengajar IPBA belum } \\
\text { intensif } & \text { melaksanakan } \\
\text { pembelajaran } & \text { IPBA } \\
\text { menggunakan } & \text { pendekatan } \\
\text { inkuiri } & \end{array}$ & $\begin{array}{l}\text { 1. Keterampilan guru pengajar IPBA } \\
\text { mengidentifikasi topik praktikum } \\
\text { masih kurang } \\
\text { 2. Kemampuan guru pengajar IPBA } \\
\text { dalam mengembangkan skenario } \\
\text { pembelajaran IPBA menggunakan } \\
\text { pendekatan inkuiri masih kurang } \\
\text { 3. Keterampilan guru dalam } \\
\text { mengelola kegiatan inkuiri masih } \\
\text { kurang }\end{array}$ & 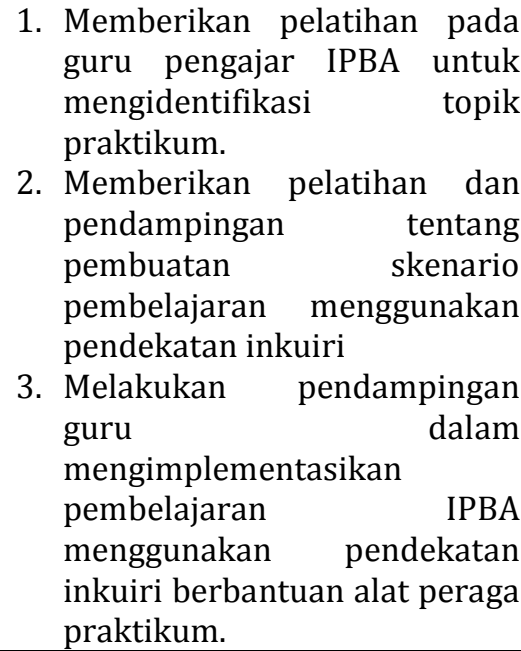 \\
\hline
\end{tabular}

Potensi lingkungan yang sangat beragam ada di sekitar sekolah sangat potensial dimanfaatkan sebagai sumber media belajar IPBA. Melalui sentuhan teknologi sederhana dan sedikit kreativitas dapat diproduksi berbagai alat peraga praktikum IPBA dengan alat sederhana yang ada di lingkungan sekitar. Dengan demikian kendala keterbatasan alat-alat dan bahan praktikum dalam pembelajaran IPBA dapat teratasi. Solusi untuk permasalahan pokok yang kedua yaitu terkait dengan mengelola pembelajaran IPBA menggunakan inkuiri discovery dilakukan dengan pembekalan metode pembelajaran dan penyegaran materi IPBA.

Tahapan kegiatan yang dilakukan dalam pelatihan adalah: (a) identifikasi konsep yang relevan dipilih sebagai topik praktikum IPBA sesuai dengan kompetensi dasar; (b) topik yang dipilih akan dijadikan fokus kegiatan inkuiri discovery; (c) pembuatan prosedur kerja praktikum (LKS); (d) Membuat alat peraga praktikum sesuai LKS; (e) merancang pembelajaran IPBA menggunakan pendekatan inkuiri discovery yang memanfaatkan alat peraga praktikum IPBA; dan (f) pendampingan guru dalam mengimplementasikan rancangan pembelajaran menggunakan pendekatan inkuiri discovery berbantuan alat peraga praktikum IPBA yang diproduksi.

Alat peraga praktikum IPBA adalah alat-alat peraga untuk Ilmu Pengetahuan Bumi dan Antariksa (IPBA), berupa seperangkat peralatan IPBA yang dikembangkan dalam penelitian hibah bersaing (Pujani, N.M, Suswandi, I., Atmaja, D.M., 2013, 2014, 2015), sehingga kegiatan dalam P2M IbM ini merupakan suatu kegiatan yang berkesinambungan atau berkelanjutan. Alat peraga IPBA yang dirancang dan dibuat ini menyerupai rangkaian peralatan uji coba ketrampilan proses pada bidang IPBA, sehingga dapat dikatakan bahwa alat peraga praktikum IPBA merupakan suatu sistem yang didesain atau dirancang secara khusus untuk suatu tujuan tertentu (Admin, 2009).

Alat peraga praktikum IPBA sangat diperlukan dalam pembelajaran IPBA karena dengan menggunakan alat peraga guru dapat terbantu dalam menjelaskan fenomena, fakta mengenai alam. Alat peraga dapat membantu siswa untuk berpikir logis dan sistematis sehingga mereka pada akhirnya mempunyai pola pikiran yang diperlukan dalam kehidupan sehari-hari (Winata Putra, dalam Suharningrum, 2010).

Pendekatan inkuiri discovery unggul dalam pembelajaran yang menekankan pada proses sekaligus produk sains (Joyce \& Weil, 1996). Pendekatan ini sangat efektif untuk meningkatkan pemahaman konsep yang mendalam dan keterampilan berpikir ilmiah (NRC, 2002). Walaupun demikian, tidak semua level berpikir dan jenis pengetahuan mesti dibelajarkan menggunakan pendekatan inkuiri discovery. Pendekatan inkuiri discovery semestinya didorong pada pembelajaran pada konsep esensial (essential concepts) yang sangat berpengaruh pada pemahaman konsep-konsep yang lain. Oleh sebab itu, identifikasi konsep esensial sesuai dengan kompetensi dasar dan hirarkinya adalah kemampuan pertama yang mesti dikuasai guru dalam mengembangkan pembelajaran menggunakan pendekatan inkuiri discovery. 
Berdasarkan hirarki konsep esensial pengkajian fakta kehidupan sehari-hari, pembelajaran yang mencakup beberapa konsep-konsep esensial dilakukan sebagai kasus untuk kegiatan inkuiri siswa, selanjutnya dirancang kegiatan inkuiri, seperti: eksplorasi gagasan awal atau hipotesis siswa, pemusatan pengamatan siswa, pembuktian hipotesis siswa, pemberian penjelasan terhadap pengamatan, elaborasi konsep sains, penarikan simpulan berdasarkan bukti, dan pemberian penjelasan terhadap fakta lain yang mirip.

Hasil analisis materi IPBA dan konteks pembelajaran dijadikan landasan untuk menyusun RPP dengan model inkuiri. Berdasarkan RPP, selanjutnya diidentifikasi apa saja yang menjadi fokus pengamatan siswa, pengamatan apa saja yang mesti diberikan penjelasan oleh siswa, dan data apa yang mesti dicatat serta dianalisis. Untuk itu, guru perlu dilatih merancang skenario pembelajaran mencakup lembar kerja siswa (LKS), alat peraga sebagai media untuk mendukung praktikum dan panduan guru dalam mengelola pembelajaran IPBA.

\section{Hasil dan pembahasan}

Sebelum pelaksanaan kegiatan utama, dilakukan kegiatan pendahuluan berupa penyegaran materi IPBA, pembekalan model pembelajaran inkuiri dan pelatihan teknik-teknik merancang alat-alat peraga IPBA. Kegiatan ini bertujuan menyegarkan pemahaman guru tentang materi praktikum IPBA. Kelompok guru pengajar IPBA di SMP dan SMA diajak mendalami bidang IPBA sesuai dengan suplemen materi IPBA dalam kurikulum IPA, Fisika, IPS dan Geografi. Dengan pelatihan ini diharapkan ingatan para guru tentang materi IPBA dapat disegarkan kembali. Setelah mengikuti kegiatan tersebut, guru-guru pengajar IPBA menyatakan bahwa pemahaman mereka tentang materi IPBA menjadi lebih baik. Mereka merasa lebih percaya diri untuk membelajarkan materi IPBA di kelas. Demikian pula pemahaman mereka mengenai model pembelajaran dengan pendekatan ilmiah (inkuiri discovery) menjadi lebih baik.

Setelah pembekalan materi, dilanjutkan dengan kegiatan utama berupa pelatihan dan pendampingan. Pelatihan 1 difokuskan untuk mensosialisasikan teknik penyusunan RPP, LKS, dan model alat peraga IPBA menggunakan pendekatan inkuiri. Materi pelatihan mencakup penjelasan tentang contoh-contoh perangkat pembelajaran inkuiri discovery dan alur kerja dalam mewujudkan semua perangkat tersebut, yaitu dari: (1) analisis konsep-konsep penting berdasarkan kompetensi dasar (KD), (2) penyusunan indikator pembelajaran, (3) penetapan topik praktikum yang digunakan dalam mendukung pembelajaran; (4) penyusunan RPP, (5) penyusunan petujuk praktikum berupa lembar kerja siswa (LKS), dan (6) pembuatan alat peraga praktikum IPBA.

Pelatihan 2, dilakukan pendampingan pembuatan perangkat pembelajaran menggunakan pendekatan inkuiri discovery terkait topik yang diidentifikasi. Kegiatan mencakup penyusunan RPP dengan pendekatan inkuiri discovery, dan pembuatan prosedur kerja praktikum berupa lembar kerja siswa (LKS). Pada pelatihan ini dilakukan pembahasan tentang draft RPP yang dibuat masing-masing guru mitra. Pada pelatihan 2 dilatihkan cara mengembangkan LKS mengacu pada RPP dan topik praktikum yang telah diidentifikasi. Diskusi secara intensif tentang fenomena dan bagaimana mengembangkan pertanyaan untuk mengarahkan cara berpikir siswa berlangsung antara guru mitra-guru mitra, dan guru mitra-tim pelaksana. Pada pelatihan ini, didampingi tim pelaksana guru mitra. Hasil kegiatan berupa RPP dan LKS.

Pelatihan 3 berupa kegiatan pendampingan pembuatan rancangan alat peraga praktikum IPBA serta alat/bahan kelengkapan keperluan praktikum sesuai LKS yang telah disusun. Alat peraga fase bulan dibuat dari kayu dan triplek. Dalam kotak berisi bola yg ditaruh ditengan-tengah kotak yang diidentifikasi sebagai bulan. Di sisi kotak ditempel lampu sebagai matahari dan saklar. Kemudian di dinding kotak dibuat lubang-lubang untuk mengintif wajah bulan pada beberapa posisi. Alat dan sekaligus bahan yang dibutuhkan untuk kegiatan praktikum sesuai petunjuk praktikum (LKS). Alat dan bahan yang dipakai sebagian besar dengan memanfaatan barang-barang yang mudah di dapat dari lingkungan sekitar. Misalnya, untuk bulan dipakai bola pingpong, untuk matahari dipakai balon lampu senter, untuk berbagai posisi matahari-bumi-bulan dipakai lubang intip. Berikut disajikan gambar (foto) beberapa contoh -alat peraga praktikum IPBA yang diproduksi. Contoh alatnya bisa dilihat pada Tabel 2 berikut. 
Tabel 02 Contoh alat peraga IPBA yang diproduksi

\begin{tabular}{lll}
\hline Gambar alat/bahan & Nama & Pemanfaatan \\
\hline & $\begin{array}{l}\text { Alat percobaan siklus } \\
\text { hidrologi }\end{array}$ & $\begin{array}{l}\text { Mengenalkan proses terjadinya siklus } \\
\text { hidrologi }\end{array}$ \\
&
\end{tabular}
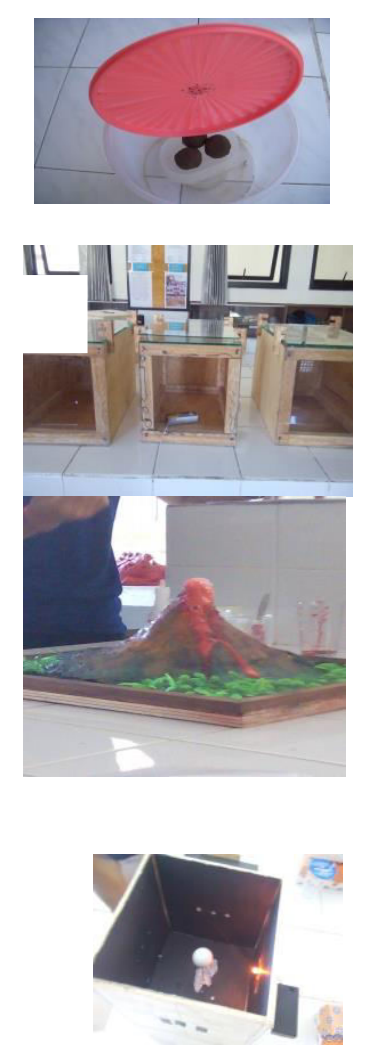

Model Alat percobaan erosi dan pelapukan

Model alat percobaan Efek Rumah Kaca

Model alat vulkanisme

Alat peraga fase bulan
Membantu mengenalkan perbedaan erosi dan pelapukan dan faktor yang mempengaruhi laju pelapukan.
Mengenalkan proses terjadinya efek rumah kaca dan faktor yang mempengaruhi efek rumah kaca.

Membantu mengenalkan proses terjadinya vulkanisme

Pelatihan 4, dilakukan Uji coba kelayakan penggunaan alat peraga/praktikum IPBA untuk menguji apakah rancangan alat tersebut sudah bisa digunakan. Setelah uji coba, selanjutnya dilakukan revisi berdasarkan masukan diberikan guru mitra. Respon yang diberikan guru menyatakan bahwa model alat peraga IPBA yang dikembangkan sudah baik dan cocok dengan keperluan pembelajaran (sesuai LKS). Dari komentar-komentar guru juga diketahui bahwa alat peraga/perangkat praktikum yang dikembangkan memiliki beberapa keuntungan, antara lain: 1) perangkat praktikum ini disesuaikan dengan kurikulum 2013 yang menuntut pembelajaran IPA SMP dilakukan dengan pendekatan ilmiah (scientific approach); 2) konten materi praktikumnya diupayakan sesuai dengan konten IPA SMP; 3) perangkat praktikum ini merujuk bahan/alat yang mudah diperoleh dari lingkungan sekitar; 4) memberikan kemudahan bagi siswa untuk melakukan kegiatan; 5) memberikan kemudahan bagi guru dalam melaksanakan proses pembelajaran dengan eksperimen karena perangkat penunjang praktikum mudah digunakan. Sementara itu, kekurangan alat peraga IPBA ini adalah (1) belum dilengkapi instruksi kerja alat, belum mencakup semua materi IPBA di Geografi, Fisika dan IPS (masih dominaan di IPA SMP), (2) petunjuk perlu dibuat lebih terstruktur agar memberi tuntunan secara mudah dan cepat kepada siswa, dan (3) perlu dilengkapi soal-soal pendalaman untuk mengeksplorasi pemahaman siswa terhadap konsep-konsep yang dibelajarkan. Berdasarkan hasil evaluasi di atas dilakukan revisi dan penyempurnaan perangkat. Pada kegiatan ini tim pelaksana mendampingi guru mitra merevisi dan melakukan penyempurnaan perangkat pembelajaran (RPP, LKS, alat peraga IPA). 
Pelatihan 5. Pada kegiatan ini dilakukan penerapan pembelajaran inkuiri discovery memanfaatkan perangkat yang telah dikerjakan oleh guru mitra. Salah seorang guru mitra tampil sebagai guru model, sementara guru-guru yang lain memantau bersama tim pelaksana. Respon siswa pada pembelajaran yang memanfaatkan perangkat praktikum lebih baik dan lebih menyenangkan daripada respon siswa pada pembelajaran konvensional (tanpa menggunakan alat peraga IPBA). Siswa menunjukkan respon positif. Dari hasil pengamatan terhadap aktivitas siswa, pada pembelajaran memanfaatkan alat peraga praktikum IPBA siswa lebih aktif dibandingkan pada pembelajaran tanpa alat peraga/praktikum. Hal tersebut menunjukkan bahwa perangkat praktikum yang dikerjakan mampu mendukung proses pembelajaran IPBA menjadi lebih menarik. Guru juga memberi respon positif terhadap alat peraga/praktikum IPBA, baik dari kemudahan mempersiapkan maupun dari kemudahan mengimplementasikannya. Dapat disimpulkan bahwa model alat peraga praktikum IPBA yang dikembangkan sudah sesuai dan mudah digunakan. Ini berarti perangkat praktikum mampu mendukung proses pembelajaran IPBA menjadi lebih menarik. Secara umum kegiatan berlangsung sesuai rencana. Guru mitra sangat antusias dan bersungguhsungguh mengikuti program-program yang telah disepakati bersama.

Dari hasil pengamatan pembelajaran, ternyata siswa yang dibelajarkan dengan pendekatan inkuiri memanfaatkan alat peraga praktikum IPBA lebih aktif dibandingkan dengan siswa yang dibelajarkan tanpa praktikum. Dengan demikian, pembelajaran IPBA yang memanfaatkan alat peraga IPBA mampu meningkatkan aktivitas dan efektivitas pembelajaran IPBA. Hal ini dapat dijelaskan bahwa pembelajaran menggunakan alat peraga praktikum IPBA merupakan pembelajaran yang berorientasi pada keterampilan proses. Implementasi pembelajaran menggunakan alat peraga praktikum IPBA memberi ruang seluas-luasnya bagi siswa untuk membangun konsep sains melalui pengalaman langsung. Model pembelajaran menggunakan praktikum memiliki karakter yang relevan dengan karakter materi pelajaran sains. Memperhatikan kesesuaian antara tuntutan materi, karakteristik IPBA, dan tuntutan tujuan pembelajaran. Dapat disimpulkan bahwa pembelajaran praktikum menggunakan alat peraga IPBA sangat relevan diterapkan pada pembelajaran IPBA.

Hal penting yang perlu diperhatikan pada pembelajaran inkuiri menggunakan praktikum berbatuan alat peraga IPBA adalah pembelajaran berpusat pada siswa (student-centered). Aktivitas pembelajaran lebih banyak memberi peluang kepada siswa untuk mengaktualisasi kreativitas berpikir dengan melakukan eksperimen secara langsung. Pembelajaran sains dilaksanakan dengan pendekatan ilmiah (scientific approach) sehingga mampu menumbuhkan kemampuan berpikir, bekerja dan bersikap ilmiah serta mengomunikasikannya sebagai aspek penting kecakapan hidup. Keterampilan proses sains menjamin siswa memperoleh pengalaman belajar yang bermakna sebab hal ini membantu siswa mengembangkan keterampilan berpikir tingkat tinggi, seperti berpikir kritis, membuat keputusan, dan pemecahan masalah (Karsli \& Sahin, 2009).

Pembelajaran IPBA dengan pendekatan inkuiri discovery dengan berbantuan alat peraga praktikum IPBA dapat memfasilitasi siswa memperoleh keterampilan-keterampilan, memelihara sikapsikap, dan mengembangkan pemahaman konsep-konsep yang berkaitan dengan pengalaman sehari-hari. Perangkat praktikum ini menyajikan materi yang dekat dengan dunia siswa, artinya bahan-bahan yang dipergunakan sudah dikenal dan mudah didapat dari lingkungan sekitar. Secara tidak langsung akan membantu siswa memahami dan mencintai lingkungan. Pembelajaran ini juga memberi ruang bagi siswa untuk melakukan discovery. Hal ini sesuai dengan pendekatan yang ditekankan dalam kurikulum 2013.

Hasil wawancara dengan guru memberi kesan positif terhadap perangkat praktikum IPBA, baik dari mudahnya mempersiapkan, maupun mudahnya menggunakan. Mudah mempersiapkan maupun menggunakan karena alat dan bahan untuk keperluan praktikum mudah didapatkan dari lingkungan sekitar.

\section{Simpulan dan saran}

Simpulan yang dapat diperoleh dari uraian di atas adalah kegiatan IbM bagi guru pengajar IPBA di SMP dan SMA Lab. Undiksha berlangsung dengan baik sesuai yang direncanakan. Guru-guru dari sekolah mitra antusias dan terlibat dengan aktif dalam mengikuti kegiatan. Hampir semua guru mitra sudah mampu meningkatkan keterampilannya dalam mengembangkan perangkat pembelajaran IPBA menggunakan pendekatan inkuiri, sudah mampu membuat alat peraga sesuai LKS yang dikembangkan, serta mampu mengimplementasikan perangkat dan alat peraga yang diproduksi dalam pembelajaran di kelas.

Saran yang dapat diajukan sebagai berikut. Alat peraga IPBA dan perangkat pembelajaran dengan pendekatan inkuiri sangat dibutuhkan oleh semua guru termasuk guru pengajar IPBA di SD, SMP maupun SMA. Kemampuan guru-guru dalam membuat alat peraga IPBA maupun menyusun perangkat 
pembelajaran perlu terus ditingkatkan. Oleh sebab itu, pengabdian masyarakat sejenis ini sangat penting didorong dan diberikan peluang yang lebih besar.

\section{Daftar Rujukan}

Admin. 2009. Alat Peraga IPA Sederhana Solusi Pembelajaran IPA di Sekolah. http://ypwi.or.id/index.php?view=article\&catid $=25 \% 3$ Apendidikan\&id=98\% 3Alat-peraga-IPAsederhana-solusi-pembelajaran-ipa-di sekolah\&format=pdf\&option=com_content. Diakses Minggu tanggal 17 Pebruari 2012.

Direktorat Pembinaan Sekolah Menengah Atas. 2011. Pedoman Pembuatan Alat Peraga Biologi Sederhana Untuk SMA. Direktorat Jenderal Pendidikan Menengah Kementerian Pendidikan dan Kebudayaan

Joyce, B. \& Weil, M. 1996. Models of Teaching (5th Ed.). Boston: Allyn and Bacon.

Kemendikbud. 2013. Kurikulum 2013, Kompetensi Dasar Sekolah Menengah Pertama (SMP)/ Madrasah Tsanawiyah (MTs).

Krajcik, J. S. and Banaszak Holl, M. M. 2012. Concurrent Enrollment in Lecture and Laboratory Enhances Student. Journal of Research in Science Teaching. Vol 49 Issue 5. May 2012. ISSN 0022-4308. online www/htt: library.wiley.com/ doi/10.1002/ tea.21016. diakses tgl. 2 September 2012

Milo Koretsky, at.al. 2011. Student Perceptions of Learningin the Laboratory: Comparison of Industrially Situated Virtual Laboratories to Capstone Physical Laboratories. Oregon State University, Education Northwest. Journal of Engineering Education. July 2011, Vol. 100, No. 3, pp. 540-573(C) 2011 ASEE. http://www.jee.org

National Research Council (NRC). 2002. Explore Inquiry and the National Science Education Standard: A Guide for Teaching and Learning. Washington: National Academy Press.

Novianti, N.R. 2011. Kontribusi Pengelolaan Laboratorium dan Motivasi Belajar Siswa Tehadap Efektifitas Proses Pembelajaran (Penelitian pada SMP Negeri dan Swasta di Kabupaten Kuningan Provinsi JawaBarat). Jurnal.Upi.Edu/File/15. Edisi Khusus No. 1, Agustus 2011. ISSN 1412-565X

Permendiknas Nomor 41 Tahun 2007 Tentang Standar Proses. 2007. (Online), (http://akhmadsudrajat.files.wordpress.com/2009/04/standar-proses-_permen-41-2007_.pdf, diakses 8 Februari 2013).

Pujani, N.M, dan Rapi N. K. 2012. Pelatihan Praktikum IPBA Bagi Guru SMP/SMA di Kota Singaraja Menuju Olimpiade Astronomi. Jurnal Pengabdian kepada Masyarakat Widya Laksana. ISSN: 14104369, Edisi Juli 2012. Hal.119-130. Singaraja: Lembaga Pengabdian Kepada Masyarakat Undiksha

Pujani, N.M, dan Rapi N. K. 2013. Pelatihan Praktikum IPBA Bagi Guru SMP/SMA di Kota Singaraja Menuju Olimpiade Kebumian. Laporan P2M. Tidak dipublikasi. Singaraja: Lembaga Pengabdian Kepada Masyarakat Undiksha.

Pujani, N.M., Sukarta, I.N, dan Yudasmara, I G.A. 2015. IbM Kelompok Guru IPA SMPN 1 Banjar dan SMPN 4 Singaraja. Laporan P2M. Tidak dipublikasi. Singaraja: Lembaga Pengabdian Kepada Masyarakat Undiksha.

Pujani, N.M, 2013. Analisis pembelajaran IPBA untuk pengembangan perangkat praktikum bagi calon guru fisika, Prosiding Seminar Nasional Riset dan Inovatif I. November 2013. ISSN:2339-1553

Pujani, N.M, 2014. Pengembangan Perangkat Praktikum Ilmu Pengetahuan Bumi dan Antariksa Berbasis Kemampuan Generik Sains Untuk Meningkatkan Keterampilan Laboratorium Calon Guru Fisika. Jurnal Pendidikan Indonesia, Lemlit Undiksha, Vol.3, No. 2. November 2014.ISSN: 2303-288X

Pujani, N.M, 2015. Keefektifan perangkat praktikum ilmu pengetahuan bumi dan antariksa dalam meningkatkan kemampuan generik sains calon guru fisika, Prosiding Seminar Nasional Riset dan Inovatif III. November 2015. ISSN:2339-1553

Santoso, T. T. 2010. Pemanfaatan Media Alam Sekitar untuk Meningkatkan Hasil Belajar Siswa dalam Pembelajaran Tematik Tema Lingkungan.Jurnal Pendidikan Kimia Tentang Media Lingkungan Sekitar. 
Subamia, I.D.P, dkk. 2012. Pelatihan Keterampilan Dasar Laboratorium (Basic Skill Laboratory) Bagi Staf Laboraorium IPA SMP Se-Kabupaten Buleleng. Jurnal pengabdian Kepada Masyarakat Widya Laksana Undiksha: Edisi Juli 2012. ISSN: 1410-4269.

Subamia, I.D.P, dkk. 2013. Analisis Kebutuhan Tata Kelola Tata Laksana Laboratorium IPA SMP di Kabupaten Buleleng. Prosiding Seminar Nasional Riset dan Inovatif. Vol.1, hal. 388-393. November 2013. ISSN:2339-1553 